\title{
Erratum
}

\section{Ansung Housing Co., Ltd v. People's Republic of China}

\author{
DEEPALOKE CHATTERJEE
}

doi:10.1017/S1474745617000398, published by Cambridge University Press, 13 October 2017.

The above case summary was published and incorrectly attributed to Maria Alcover. The correct author is Deepaloke Chatterjee. Cambridge University Press apologizes for this error and any inconvenience it may have caused.

\section{Reference}

Chatterjee, D. (2017). Ansung Housing Co., Ltd. v. People's Republic of China. World Trade Review, 16(4): 737-740. 